This is a version of a chapter published in: Bertotti, Sara, Heathcote, Gina, Jones, Emily and Labenski, Sheri (2021) The Law of War and Peace: A Gender Analysis. Volume 1. London: Bloomsbury / Zed Books.

The version of record is available at: https://doi.org/10.5040/9780755637836 Not for re-distribution or re-use Accepted version downloaded from SOAS Research Online: http://eprints.soas.ac.uk/36133

\title{
THE LAW OF WAR AND PEACE
}

\author{
A Gender Analysis
}




\title{
THE LAW OF WAR AND PEACE
}

\author{
A Gender Analysis
}

\author{
Vol 1
}

Sara Bertotti, Gina Heathcote,

Emily Jones, Sheri Labenski

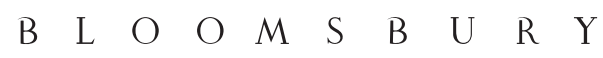

LONDON $\cdot$ NEW DELHI NEW YORK $\cdot$ SYDNEY 
The Law of War and Peace: A Gender Analysis: Vol 1 was first published in 2021 by Zed Books Ltd, Bloomsbury

Publishing, 50 Bedford Square, London, WC1B 3DP www.bloomsbury.com

Copyright ( Sara Bertotti, Gina Heathcote, Emily Jones, Sheri Labenski, 2021

The right of Sara Bertotti, Gina Heathcote, Emily Jones, and Sheri Labenski to be identified as the authors of this work has been asserted by them in accordance with the Copyright, Designs and Patents Act, 1988

Typeset by Integra Software Services Pvt. Ltd.

Cover design by [TBC]

Printed and bound in Great Britain

All rights reserved. No part of this publication may be reproduced, stored in a retrieval system or transmitted in any form or by any means, electronic, mechanical, photocopying or otherwise, without the prior permission of Zed Books Ltd.

A catalogue record for this book is available from the British Library

ISBN: HB: 978-1-7869-9668-8 ePDF: $\quad 978-1-7869-9670-1$ ePUB: $\quad 978-1-7869-9671-8$ 


\section{CONTENTS}

Author Biographies vi vil

Table of Cases vii

Abbreviations $\quad$ ix

INTRODUCTION 1

Chapter 1

COLLECTIVE SECURITY 43

Chapter 2

$\begin{array}{ll}\text { UNILATERAL FORCE } & 79\end{array}$

Chapter 3

COUNTERING TERRORISM

Chapter 4

INTERNATIONAL HUMANITARIAN LAW OF

ARMED CONFLICT

Chapter 5

INTERNATIONAL CRIMINAL LAW

Bibliography

Index 


\section{AUTHOR BIOGRAPHIES}

Sara Bertotti is a Doctoral Candidate and Graduate Teaching Assistant at the School of Law, SOAS University of London.

Gina Heathcote is a Reader in Gender Studies and International Law, at the Centre for Gender Studies and the School of Law, SOAS University of London.

Emily Jones is a Lecturer in the School of Law and Human Rights Centre at the University of Essex.

Sheri Labenski is a Research Officer in the Centre for Women, Peace, and Security at the London School of Economics and Political Science, where she works on an ERC-funded project Gendered Peace. 


\section{TABLE OF CASES}

Reparation for Injuries Suffered in the Service of the United Nations (Advisory Opinion) [1949] ICJ Rep 174

Legal Consequences for States of the Continued Presence of South Africa in Namibia (South West Africa), notwithstanding Security Council Resolution 276 (1970) (Advisory Opinion) [1971] ICJ Rep 16

Military and Paramilitary Activities in and against Nicaragua

(Nicaragua v United States of America) (Merits) [1986] ICJ Rep 14

Prosecutor v Tadić, Decision on the Defence Motion for Interlocutory Appeal on Jurisdiction, Case IT-94-1, 2 October 1995

Legality of the Threat or Use of Nuclear Weapons (Advisory Opinion) [1996] ICJ Rep 226

Prosecutor v Tadić, Opinion and Judgement, Case IT-94-1-T, 7 May 1997

Prosecutor v Akayesu, Judgement, Case ICTR-96-4-T, 2 September 1998

Prosecutor v Mucić et al, Judgement, Case IT-96-21-T, 16 November 1998

Prosecutor v Kayishema et al, Judgement, Case ICTR-95-1-T, 21 May 1999

Prosecutor v Tadić, Judgement in Sentencing Appeals, Case IT-94-1-A, 26 January 2000

Prosecutor v Plavšić, Initial Indictment, Case IT-00-39 \& 40/1, 3 April 2000

Prosecutor v Nyiramasuhuko and Ntahobali, Amended Indictment, Case ICTR-97-21-I, 1 March 2001

Prosecutor v Todorović, Sentencing Judgement, Case IT-95-9/1-S, 31 July 2001 
Prosecutor v Kunarac et al, Judgement, Case IT-96-23 \& 23/1-A, 12 June 2002

Prosecutor v Simić, Sentencing Judgement, Case IT-95-9/2-S, 17 October 2002

Prosecutor v Plavšić, Sentencing Judgement, Case IT-00-39 \& 40/1-S, 27 February 2003

Oil Platforms (Islamic Republic of Iran v United States of America) (Merits) [2003] ICJ Rep 161

Prosecutor v Češić, Sentencing Judgement, Case IT-95-10/1-S, 11 March 2004

Legal Consequences of the Construction of a Wall in the Occupied Palestinian Territory (Advisory Opinion) [2004] ICJ Rep 136

A and Others v Secretary of State for the Home Department [2004] UKHL 56 (Belmarsh Case)

Independent Counsel v Brima et al, Sentencing Judgement in Contempt Proceedings, Case SCSL-2005-02 and Case SCSL-200503, 21 September 2005

Prosecutor v Alex Tamba Brima, Brima Bazzy Kamara and Santigie Borbor Kanu, Judgment, Case SCSL-04-16-A, 22 February 2008

A and Others v the United Kingdom ECHR (Application no. 3455/05) 19 February 2009

Prosecutor v Nyiramasuhuko et al, Judgement and Sentence, Case ICTR-98-42-T, 24 June 2011

Prosecutor v Simone Gbagbo, Warrant of Arrest, Case ICC-02/1101/12, 29 February 2012

Co-Prosecutors v Ieng Thirith, Decision on Reassessment of Accused Ieng Thirith's Fitness to Stand Trial Following Supreme Court Chamber Decision of 13 December 2011, Case 002/19-09-2007/ ECCC/TC, 13 September 2012

Co-Prosecutors v Im Chaem, Closing Order Disposition, Case 004/1/07-09-2009-ECCC/OCIJ, 22 February 2017 


\section{ABBREVIATIONS}

$\begin{array}{ll}\text { ATCSA } & \text { Anti-Terrorism, Crime and Security Act, UK } \\ \text { ATT } & \text { Arms Trade Treaty } \\ \text { CEDAW } & \text { Convention on the Elimination of All Forms of } \\ & \text { Discrimination Against Women } \\ \text { CPN-M } & \text { Communist Party of Nepal-Maoist } \\ \text { COI } & \text { Commission of Inquiry } \\ \text { COIN } & \text { Counterinsurgency } \\ \text { DRC } & \text { Democratic Republic of the Congo } \\ \text { ECCC } & \text { Extraordinary Chambers in the Courts of Cambodia } \\ \text { ECHR } & \text { European Convention on Human Rights } \\ \text { ECtHR } & \text { European Court of Human Rights } \\ \text { FET } & \text { Female Engagement Team } \\ \text { HRA } & \text { Human Rights Act, UK } \\ \text { HRC } & \text { Human Rights Council } \\ \text { ICC } & \text { International Criminal Court } \\ \text { ICCPR } & \text { International Covenant on Civil and Political Rights } \\ \text { ICJ } & \text { International Court of Justice } \\ \text { ICRC } & \text { International Committee of the Red Cross } \\ \text { ICTR } & \text { International Criminal Tribunal for Rwanda } \\ \text { ICTY } & \text { International Criminal Tribunal for the former Yugoslavia } \\ \text { IMT } & \text { International Military Tribunal } \\ \text { IMTFE } & \text { International Military Tribunal for the Far East } \\ \text { INGO } & \text { International Non-Governmental Organization } \\ \text { ISIS } & \text { Islamic State of Iraq and Syria } \\ \text { LAWS } & \text { Lethal Autonomous Weapons Systems } \\ \text { LGBT } & \text { Lesbian, Gay, Bisexual, Transgender } \\ \text { LGBTQ } & \text { Lesbian, Gay, Bisexual, Transgender, Queer } \\ \text { LGBTQIA } & \text { Lesbian, Gay, Bisexual, Transgender, Queer, Intersex, Asexual } \\ \text { NATO } & \text { North Atlantic Treaty Organization } \\ \text { NGO } & \text { Non-Governmental Organization } \\ \text { OHCHR } & \text { Office of the United Nations High Commissioner for Human } \\ & \text { Rights } \\ \text { OTP } & \text { Office of the Prosecutor } \\ \text { PLA } & \text { People's Liberation Army, Nepal } \\ \text { R2P } & \text { Responsibility to Protect } \\ \text { RNA } & \text { Royal Nepal Army } \\ \text { SCSL } & \text { Special Court for Sierra Leone } \\ \text { STL } & \text { Special Tribunal for Lebanon } \\ & \end{array}$


TADA Terrorist and Disruptive Activities (Control and Punishment) Act, Nepal

TADO Terrorist and Disruptive Activities (Control and Punishment) Ordinance, Nepal

UN United Nations

USAID

United States Agency for International Development

WILPF Women's International League for Peace and Freedom Second World War 


\section{INTRODUCTION}

...feminism is a mode of analysis, a method of approaching life and politics, a way of asking questions and searching for answers, rather than a set of political conclusions about the oppression of women. ${ }^{1}$

... an exception is made in favour of women and children ... ${ }^{2}$

Peace and war are predominantly understood in opposition to one another; likewise, understandings of security and insecurity or the assumed binary between men and women.

Peace is thus imagined as distinct from war, to be achieved at the end of hostilities and, significantly, given lesser research, resources and attention from international and state institutions. This can also be seen in academic curricula where war studies or strategic studies outnumber peace studies and peace research. ${ }^{3}$ This book is one of a two-volume set analysing international laws on peace and war from a gender perspective.

Seventeenth-century scholar Hugo Grotius is famously known for his treatise De Jure Belli ac Pacis, or On the Law of War and Peace, one of the earliest, and most influential, international legal texts that is often still referenced in international legal scholarship today. ${ }^{4}$ Grotius' book delineated the different obligations of states in times of war, which he perceived as an appropriate means to achieve peace, ${ }^{5}$ while

1. Nancy Hartsock, 'Feminist Theory and the Development of Revolutionary Strategy' in Zillah R Eisenstein (ed), Capitalist Patriarchy and the Case for Socialist Feminism (Monthly Review Press 1978) 58, 59

2. Hugo Grotius, On the Law of War and Peace (trans. Archibald Colin Campbell, Anodos Books 2019) 182

3. Carol Cohn, 'Women and Wars: Toward a Conceptual Framework' in Carol Cohn (ed), Women and Wars: Contested Histories, Uncertain Futures (Polity Press 2013) 12

4. Grotius, above note 2

5. ' $\ldots$ and then war itself will lead us to peace, as to its proper end.' Grotius, above note 2,11 
advancing the notion of an international society. ${ }^{6}$ Although Grotius did not conceive of gender as central to international law, his analysis is built on an analogy between the power of the patriarch and the power of the state. ${ }^{7}$ As the quote above attests, Grotius saw women and children as a separate class of subjects, defined by an entitlement to protection, during war. ${ }^{8}$ In contrast, this book analyses war and peace as interlocking, gender as diverse and fluid, and security as gendered. Our account of the law of war and peace analyses contemporary laws, including collective security, unilateral force and counter-terrorism as well as the legal regimes governing the international humanitarian law of armed conflict and international criminal law. The book, and the forthcoming second volume, approaches peace and war as intertwined while analysing these laws through the lens of gender. Throughout, the text draws in feminist analyses of international law, gender and conflict. ${ }^{9}$ While the laws of war and peace have changed in many ways since Grotius' day, we analyse the entrenched assumptions about gender that persist in the law of war and the law of peace. In positioning law in our analysis of gender and conflict, we add to the development of gender and conflict as a field of research through an in-depth study of the relevant legal regimes. ${ }^{10}$

As a gender analysis, our starting point is Duncanson's definition of gender as functioning as an individual identity and as a symbolic system, requiring attention to the embodied realities of gendered lives and the nexus to larger power relations. ${ }^{11}$ Duncanson identifies the limitations of perceiving gender as simply an individual identity and the centring of women as a named group that experiences discrimination,

6. Hedley Bull, Benedict Kingsbury and Adam Roberts (eds), Hugo Grotius and International Relations (Clarendon Press 1992) 6ff

7. Helen Kinsella, 'Gendering Grotius: Sex and Sex Difference in the Laws of War' (2006) 34 (2) Political Theory 170, 171

8. Also, Grotius, above note 2, 191

9. Hilary Charlesworth and Christine Chinkin, The Boundaries of International Law: A Feminist Analysis (Manchester University Press 2000); Gina Heathcote, Feminist Dialogues on International Law: Successes, Tensions, Futures (Oxford University Press 2019)

10. Cynthia Cockburn and Dubravka Zarkov (eds), The Postwar Moment: Militaries, Masculinities and International Peacekeeping (Lawrence and Wishart 2002); Cynthia Enloe, Maneuvers: The International Politics of Militarizing Women's Lives (University of California Press 2000)

11. Claire Duncanson, Gender and Peacebuilding (Polity Press 2016) 7 
which reinforces an essentialist and heteronormative binary account of gender. This approach writes out women's diversity as well as the diversity of gendered lives. Similarly, legal outcomes focused on gender as a marker of identity tend towards liberal feminist framings focused on rights and the individual; the production of quotas for participation; and result in limited means to address heteronormativity, as well as raced and ableist experiences of gender. ${ }^{12}$ Through identifying gender as an identity marker while addressing gender as a symbolic system, gender analysis is developed through the examination of systems and structures of meaning as well as institutions. ${ }^{13}$ In applying this approach to the study of armed conflict and peace processes, we acknowledge the lived experience of gender as consequence of symbolic structures and systems of meaning, including law.

Studies of gender and conflict have identified the war-peace dichotomy as a false, gendered binary. ${ }^{14}$ Our project is to think more deeply, ask more questions and theorize beyond war and peace to consider how war and peace are equally invested in each other: peacetime states are never wholly peaceful and those at war, or - to use the terminology of contemporary international lawyers - in a situation of armed conflict, are also, always, invested in peace. ${ }^{15}$ As a consequence, across this book, and the forthcoming second volume, we develop an analysis that interrogates the gendered meanings of peace and armed conflict to understand the persistence of military behaviour and the complexities of peace. Both texts shift between diverse feminist, queer and gender tools as well as locations of violence, from macro to micro sites, to challenge legal boundaries between peace and conflict, security and insecurity, masculine and feminine forms. In analysing peace and war, security and insecurity, the objective is to avoid a tokenistic

12. Ratna Kapur, Erotic Justice: Law and the New Politics of Postcolonialism (Routledge 2005); Gina Heathcote, 'Participation, Gender and Security' in Gina Heathcote and Dianne Otto (eds), Rethinking Peacekeeping, Gender Equality and Collective Security (Palgrave 2014)

13. Carol Cohn (ed), Women and Wars: Contested Histories, Uncertain Futures (Polity Press 2013)

14. Cynthia Cockburn, The Space between Us: Negotiating Gender and National Identities in Conflict (Zed Books 1998)

15. Dianne Otto, Rethinking Peace from a Queer Feminist Perspective, 26 September 2019, Public Lecture at LSE Centre for Women, Peace and Security, London 
treatment of peace as an afterthought of armed conflict. If Grotius' writing makes a series of assumptions around the role and persistence of the patriarch in the framing of law, this text takes its starting point from the role and persistence of feminisms as tools for dismantling the legacy of patriarchy in laws. The book, and the forthcoming second volume, adds an important perspective to the study of gender and conflict.

As authors we have different points of view, sometimes with quite radical divergences, on what a feminist analysis might look like. The use of the pronoun 'we' thus holds our disagreements, tensions and conversations - what Cockburn refers to as the 'space between us' as productive moments in the writing of the text. ${ }^{16}$ While Cockburn articulates this as a feminist methodology for creating alliances across (imagined and real) differences in armed conflict, our commitment has been to explore how our differences as authors have the capacity to inflect and change the text via recognition of these 'spaces between us. More concretely, these differences are reflected in our theoretical choices (from theories of gender and sexuality, queer scholarship to intersectionality and postcolonial theories, from feminist international relations work to feminist legal theories) alongside strongly held commitments to feminist peace activism, to addressing the reality of female violence, to the politics of the everyday and through posthuman and queer feminisms that we have held, drawn in, discussed and sat with across both texts: as such, we ask the reader to regard what we describe as a feminist methodology as one which questions our differences, our assumed knowledges and sometimes our disagreements as authors.

In the following section we introduce the key debates on gender and international law, as well as law and war, before presenting the contours of our methodology, exploring the feminist convergences, conversations and differences that inform our overarching methodology. Throughout the book different components of the methodology - structural bias, intersectionality, queer and postcolonial feminisms, while moving towards a feminist anti-militarism - are explored chapter by chapter. The third section of this chapter introduces the Security Council resolutions on women, peace and security, noting the prominent place that the women, peace and security resolutions hold in the bulk of academic writing on gender and conflict and seeking to both draw on these resolutions as important tools and set forth strategies to develop

16. Cockburn, above note 14; Robyn Wiegman, Object Lessons (Duke University Press 2012) 13 
research on law regulating armed conflict and peace processes beyond the women, peace and security agenda. ${ }^{17}$ We hope, as reader, you are able to engage with a range of feminist methodologies via the two volumes, as well as the various international legal regimes that govern war and peace. In the final section of this introductory chapter, we outline the structure of Volume One and provide a short insight into the focus of Volume Two.

\section{Gender in international law, war and peace}

This section introduces some of the key terminologies and concepts used throughout the book. One of our goals in the book is to highlight the range of international laws that regulate armed conflict, looking at both jus ad bellum and jus in bello. The jus ad bellum, or the law on resorting to war, governs the decisions of states to use military force. The jus in bello, or law in war, governs the conduct of hostilities, incorporating the methods and means of armed conflict, as well as the humanitarian restraints and protections that apply. In Volume One, we also provide an analysis of international criminal law, the key international legal regime for holding individuals accountable for international crimes. In focusing on these legal regimes, our goal is to address a larger gap in the literature on gender and conflict that primarily focuses on a narrow range of international instruments: the Security Council resolutions on women, peace and security, which we discuss below, and the international criminal laws that address gender crimes, which we discuss in Chapter $5 .{ }^{18}$ Throughout, we argue for an expansive gender analysis of conflict that addresses international law through the laws that govern war and peace. We commence the project in this volume through an analysis of collective security, unilateral force and counter-terrorism and the relevant legal regimes, followed by a gender analysis of the international humanitarian law of armed conflict and international criminal law. Volume Two provides analysis

17. Sara E Davies and Jacqui True (eds), The Oxford Handbook of Women, Peace, and Security (Oxford University Press 2019)

18. Vasuki Nesiah, 'Gender and Forms of Conflict: The Moral Hazards of Dating the Security Council' in Fionnuala Ní Aoláin, Naomi Cahn, Dina Francesca Haynes and Nahla Valji (eds), The Oxford Handbook on Gender and Conflict (Oxford University Press 2018) 
of military technologies, peace agreements, peacekeeping and peace enforcement, as well as alternative transitional justice mechanisms and feminist peace activism. In both volumes we examine the impact of the various regimes on both peacetime states and states understood to be at war, identifying and disrupting the assumption that peacetime states are not co-opted and affected by global conflicts.

\section{Gender and international law}

Charlesworth and Chinkin's work on feminist approaches to international law moves from a focus on the effects of international law on gendered lives to interrogate the ways in which gender structures international law. ${ }^{19}$ Elsewhere, Charlesworth analyses the ways in which multiple gendered binaries both underpin and uphold international legal structures. This includes legal perceptions of 'objective/ subjective, legal/political, logic/emotion, order/anarchy, mind/body, culture/nature, action/passivity, public/private, protector/protected.'. International law primarily values the first (male) characteristic over the second characteristic, which is deemed to be feminized, thereby not only working to present international law as an inherently masculine structure, but also enforcing gender stereotypes more broadly. ${ }^{21}$ Otto explains:

Dichotomized ideas that are associated with gender, like strength and weakness, are also organized hierarchically so that the masculine option is valued more highly than the feminine. Associating a course of action with weakness immediately gives the alternative course the connotation of strength. Thus gendered dichotomies provide a powerful means of shaping what appear to be "common sense" choices. ${ }^{22}$

This deep structural constraint in law also makes addressing gender beyond a binarized articulation difficult whilst also embedding a

19. Charlesworth and Chinkin, above note 9

20. Hilary Charlesworth, 'International Law: a Discipline of Crisis' (2002)

65 (3) Modern Law Review 377, 389-90

21. Ibid.

22. Dianne Otto, 'A Sign of "Weakness"? Disrupting Gender Certainties in the Implementation of Security Council Resolution 1325’ (2006) 13 Michigan Journal of Gender \& Law 113, 122 
heteronormative relation between masculinity and femininity. Gender as an analytical tool thus emerges within international legal scholarship as a means to expose and uncover these deep structural biases.

Race, class, sexuality, ableism and socio-economic status, among other factors, all contribute towards the biopolitical ordering of individuals, as well as contributing to the normative values which underpin international legal frames. ${ }^{23}$ Gender must therefore be understood as intersecting with these other organizing structures. Intersectionality as articulated by Crenshaw, who coined the term through drawing on a much longer history of Black feminist approaches, highlights the necessity of understanding gender through an intersectional lens and recognizing 'the "multidimensionality" of marginalized subjects' lived experiences. ${ }^{24}$ While Crenshaw's work on intersectionality was borne from a US anti-discrimination law perspective, it has influenced the way scholars articulate the convergence of identities before the law. Yuval-Davis has expanded the work on intersectionality to include the way political arrangements and concepts such as citizenship (both formal and informal), indigeneity and migration influence the lives of individuals in international and local spaces. ${ }^{25}$ While Yuval-Davis' work may not necessarily engage with intersectionality in international law in specific terms, her work illustrates the need for a thorough discussion of identity politics within international discourse, and indeed its presence in human rights and women's rights on a global scale. ${ }^{26}$

Within gender scholarship on international law, intersectionality is foremost identified and analysed in relation to the Convention on the Elimination of All Forms of Discrimination Against Women

23. Michel Foucault, The Will to Knowledge: The History of Sexuality Volume 1 (1976, trans. Robert Hurley, Penguin 1998); as a starting point, biopolitics can be understood as a form of positive politico-administrative power over life 'to ensure, sustain, and multiply life, to put this life in order .... Foucault, at 138

24. Jennifer Nash, 'Re-thinking Intersectionality' (2008) 89 Feminist Review 1, 2 Kimberlé Crenshaw, 'Demarginalizing the Intersection of Race and Sex: A Black Feminist Critique of Antidiscrimination Doctrine, Feminist Theory and Antiracist Politics' (1989) 1 The University of Chicago Legal Forum 139; Jennifer Nash, Black Feminism Reimagined: After Intersectionality (Duke University Press 2019)

25. Nira Yuval-Davis, 'Intersectionality and Feminist Politics' (2006) 13 (3) European Journal of Women's Studies 193

26. Yuval-Davis, ibid. 
(CEDAW) ${ }^{27}$ Although CEDAW, as an anti-discrimination treaty, does not address intersectionality in its text, its application and interpretation via the CEDAW Committee is regarded as developing an intersectional feminist agenda. ${ }^{28}$ The CEDAW Committee, via its General Recommendations, has also broadened the range of the treaty to address violence against women and women in conflict prevention, conflict and post-conflict situations. ${ }^{29}$ The CEDAW Committee has also specifically addressed the needs of disabled women, rural women, migrant women and refugee and stateless women. ${ }^{30}$ This represents an important effort at gender law reform within international law. Nevertheless, CEDAW's interventions remain circumscribed by the language of women's rights: a legal model that centres liberal ideologies and prioritizing the individual in adversarial legal systems that also underpins neoliberal market logics. ${ }^{31}$ Although the development of the

27. Convention on the Elimination of All Forms of Discrimination against Women (18 December 1979) 1249 UNTS 13

28. Meghan Campbell, 'CEDAW and Women's Intersecting Identities: A Pioneering New Approach to Intersectional Discrimination' (2015) 11 (2) Direito GV Law Review 479; Lola Okolosie, 'Beyond “Talking” and "Owning” Intersectionality' (2014) 108 Feminist Review 90

29. Committee on the Elimination of Discrimination against Women, 'General Recommendation No. 35 on gender-based violence against women, updating General Recommendation No. 19' (26 July 2017) UN Doc. CEDAW/C/ GC/35; Committee on the Elimination of Discrimination against Women, 'General Recommendation No. 30 on women in conflict prevention, conflict and post-conflict situations' (1 November 2013) UN Doc. CEDAW/C/GC/30

30. Committee on the Elimination of Discrimination against Women, 'General Recommendation No. 18, tenth session, 1991, disabled women' (30 January 1992) UN Doc. A/46/38; Committee on the Elimination of Discrimination against Women, 'General Recommendation No. 26 on women migrant workers' (5 December 2008) UN Doc. CEDAW/C/2009/WP.1/R; Committee on the Elimination of Discrimination against Women, 'General Recommendation No. 32 on the gender-related dimensions of refugee status, asylum, nationality and statelessness of women' (14 November 2014) UN Doc. CEDAW/C/GC/32; Committee on the Elimination of Discrimination against Women, 'General Recommendation No. 34 on the rights of rural women' (7 March 2016) UN Doc. CEDAW/C/GC/34

31. Rosemary Hunter, 'Contesting the Dominant Paradigm: Feminist Critiques of Liberal Legalism' in Margaret Davies and Vanessa Munro (eds), The Ashgate Research Companion to Feminist Legal Theory (Ashgate 2013) 
CEDAW provisions-its recommendations and reports are an important element of international law, and via General Recommendation 30 are explicitly linked to the women, peace and security agenda-they remain outside the key focus of this book because of the limited mode of intersectionality that we perceive as achievable within a rights framework that, we argue, risks collapsing back into a set of competing identity claims. ${ }^{32}$ Nonetheless, in the chapter on collective security we utilize the CEDAW Committee's work on Syria, which has incorporated a multifaceted gender approach to gendered harms. The UN system has largely ignored the need for a gender analysis in their response to the armed conflict in Syria. However, the CEDAW Committee has challenged the Syrian government on their incorporation of the women, peace and security agenda and on a broader politico-socio-economic understanding of gendered harm, which demonstrates the importance of feminist work via the CEDAW Committee. We recognize that while CEDAW can offer a limited rights-based framework at times, it remains an important avenue for engagement within the current international legal order.

We understand intersectionality as a feminist tool that is necessary to identify how power and privilege operate in tandem across dominant categories of gender, race, class, sexuality and ableism. We regard any approach to gender that is isolated from analysis of these co-ordinating sites of privilege as likely to produce gains for women who otherwise match the privilege of those in power. This remains a limitation of gender law reform within international law that has often empowered actors in the global north while seeking to 'save' and 'protect' women in the global south. ${ }^{33}$ Both the global and intra-state dynamics of race and the histories of imperialism, we argue, must be addressed within structural bias feminisms through a feminist methodological commitment to seeing gender as produced in intersection with other spaces of power and privilege. Otto describes this as a need to push against,

the reliance on essentialist and imperial representations of women as pacifying and civilizing influences because these representations, ironically, bear an unsettling resemblance to the gender stereotypes that sustain militarism and women's inequality. ${ }^{34}$

32. Heathcote, above note 9 , ch 5

33. Kapur, above note 12

34. Otto, above note 22,115 
Developing the commitment to intersectionality and with a desire to actively respond to the heteronormativity of the gender binary, our work draws on both queer and postcolonial feminist approaches to international law. Queer approaches to international law provide an opportunity to question the hetero/normative underpinnings of the international legal structure. Queer approaches, like feminist approaches, cut across many layers of analysis, from focusing on the lived experiences of LGBTQIA persons, to understanding the ways in which the law applies to LGBTQIA subjects unequally, ${ }^{35}$ to approaches which seek to unsettle the normative underpinnings of international legal structures via 'changing meanings, unsettling taxonomies, and inverting conventions. ${ }^{36}$ These two volumes thus draw on both feminist methodologies and queer approaches at different times to understand the gendering of the law and conflict.

Postcolonial feminisms are also drawn on to highlight the colonial histories and imperialism which have structured much of international law and gender law reform. The histories and the present of feminism are interrogated in terms of their co-optation into the denial of alternative histories of knowledge, the dominance of militarycapital and the legacies of colonialism in international law and in the

35. We have chosen to use the term LGBTQIA, as opposed to LGBT. We regard this as a conscious departing from liberal LGBT rights frameworks through focusing on queer approaches, as well as encompassing a wider range of identities. LGBTQIA standing for lesbian, gay, bisexual, transgender, queer, intersex and asexual. A number of identity categories which we would wish to include are still missing, including, for example, trans people who do not identify as transgender, non-binary and genderqueer people. The semiotic challenge exemplifies one of the core problems with identity politics which seek to label subjects who do not neatly fit into labels or chose not to be labelled. At the same time, we have chosen to use LGBTQIA here as opposed to queer because we are talking about lived subjects who may or may not identify with queer as an all-encompassing anti-identity. For an analysis of LGBTQIA in a legal frame, see Sara Bengtson, Damian Gonzalez-Salzberg, Loveday Hodson and Paul Johnson, 'Christine Goodwin v the United Kingdom' in Loveday Hodson and Troy Lavers (eds), Feminist Judgments in International Law (Hart Publishing 2019)

36. Dianne Otto, 'Introduction: Embracing Queer Curiosity' in Dianne Otto (ed), Queering International Law: Possibilities, Alliances, Complicities, Risks (Routledge 2018) 2 
deployment of military force. For example, to 'save' women in the global south from the violence of local military and political actors. ${ }^{37}$ Drawing on Kapur's articulation of peripheral subjects and the construction of victim feminisms, we are mindful of the means through which dominant discourses on gender and conflict within international law deploy global distinctions between gendered empowerment and gendered protection. ${ }^{38}$ This informs our framing of Chapters 4 and 5 where the hyperfocus on conflict-related sexual violence in international humanitarian law and international criminal law prompts our study of additional gendered discourses, including female violence, carceral feminisms and feminist posthumanism.

We have purposefully chosen to name these two books 'a gender analysis' so as to encompass all these perspectives, noting the links between multiple feminist and queer approaches. ${ }^{39}$ At the same time, we are mindful of the ways in which 'gender' has often been taken up at an international level so as to refer to women only. This narrowing down of the term 'gender' creates a problematic and essentialist version of gender in international law and potentially silences any focus on subjects who do not neatly fit into the gender binary while fostering a lack of focus on the role of masculinities in enforcing the gender binary. ${ }^{40}$ Ultimately, this study therefore conceptualizes the nexus between gender and international law as a linchpin that encourages the delving into further analysis on multiple, intersecting identities, lived experiences and structures, bringing in race, class, political economy, sexuality, ableism, geographic location and other factors

37. Chandra Talpade Mohanty, 'Under Western Eyes: Feminist Scholarship and Colonial Discourses' (1988) 30 Feminist Review 61; Vasuki Nesiah, 'The Ground Beneath Her Feet: “Third World” Feminisms' (2003) 4 (3) Journal of International Women's Studies 30; Vasuki Nesiah, 'From Berlin to Bonn to Baghdad: A Space for Infinite Justice’ (2004) 17 Harvard Human Rights Journal 75; Vasuki Nesiah, 'Resistance in the Age of Empire: Occupied Discourse Pending Investigation' (2006) 27 (5) Third World Quarterly 903

38. Kapur, above note 12

39. Martha Albertson Fineman, Jack E Jackson and Aman P Romero (eds), Feminist and Queer Legal Theory: Intimate Encounters, Uncomfortable Conversations (Ashgate 2009)

40. Dianne Otto 'International Human Rights Law: Towards Rethinking Sex/Gender Dualism' in Margaret Davies and Vanessa Munro (eds), The Ashgate Research Companion to Feminist Legal Theory (Ashgate 2013) 
to question power and governance and to challenge the normative underpinnings of the international legal order.

A related feminist critique of gender law reform within international law centres on the problematizing of governance feminism, defined as 'every form in which feminists and feminist ideas exert a governing will within human affairs, ${ }^{41}$ noting the engagement feminism has with the work of 'state, state-like, and state-affiliated power. ${ }^{42}$ Highlighting that governance feminism has produced many positives in regards to international legal jurisprudence and feminist law reform, Halley also acknowledges that governance feminism has produced 'terrible mistakes', which are important to 'take stock of'.43 One such example of governance feminism can be seen in the ways in which some feminist actors, alongside other actors, have sought to use military interventions in order to 'protect' women's rights. Such a perspective ignores the impact of military interventions on women's lives while also allowing women's rights to be used to justify interventions that are often about a wider political will. Critiques of governance feminism are careful to point out that not all feminisms are given space within the 'halls of power. ${ }^{44}$ Mindful of the critique of governance feminisms, in these two volumes we seek to critique such modes of engagement while applying analyses that have largely been left outside of the 'halls of power', including, as highlighted above, intersectional, queer and postcolonial gender perspectives. These are feminist approaches that remain on the peripheries of mainstream international legal thought, even with the small erosions into the world of CEDAW via the use of increasingly intersectional approaches. In applying these feminist approaches we seek to imagine an alternative gender approach to international law and conflict that challenges the multiple structural biases that continue to permeate the current international legal order and the regulation of armed conflict, war and peace.

41. Janet Halley, 'Preface: Introducing Governance Feminism' in Janet Halley, Prabha Kotiswaran, Rachel Rebouché and Hila Shamir (eds), Governance Feminism: An Introduction (University of Minnesota Press 2018) ix

42. Halley, ibid., $x$

43. Halley, ibid.

44. Janet Halley, Split Decisions: How and Why to Take a Break from Feminism (Princeton University Press 2006) 21 
In centring diverse feminist methodologies we, on the one hand, clearly exercise a series of choices and, on other hand, have actively incorporated methodologies that underscore alternative and varying voices from those that dominate dialogues on gender and conflict within global governance. Following Kapur's account of peripheral subjects, this methodology is used to regard actors outside of dominant knowledge frameworks as equally, indeed perhaps better, situated to contribute to understandings of war, peace and law. ${ }^{45}$ At the same time our approach to gender as a tool for law reform actively engages intersectional assemblages as a mechanism for thinking about gender's investment in power relations, in particular the production of heteronormativity in law, the privileging of able-ism/normalizing of bodies and western-derived histories of knowledge and law.

\section{Gender and armed conflict}

An important contribution to the international legal literature on gender and armed conflict is Charlesworth's account of international law as a discipline of crisis. ${ }^{46}$ Charlesworth discusses the roles of men and women in crisis situations, identifying how women are only recognized as being a part of the crisis, and international legal processes post-conflict, when harms are regarded as constituted against women as a social group (e.g. mass rapes and sexual assaults) while systemic and structural violence is perceived as disconnected from conflictrelated violence. ${ }^{47}$ Charlesworth's analysis exemplifies how men are seen to be active agents, while women enter only as an afterthought to the regulation of armed conflict. ${ }^{48}$ At the same time, while men are often seen as defendants or perpetrators in wartime they are also simultaneously the 'saviour' who solves the crisis, rescuing women in the process. This feeds into the crisis mentality of international law limiting the analysis of how international law itself reflects gendered conceptualizations of violence and security. We are mindful that we too are guilty of focusing on these moments of crisis in order to engage with the literature in the area of gender and conflict. This anxiety thus reflects the tension feminists find themselves facing in international

45. Kapur, above note $12,128-36$

46. Charlesworth, above note 20

47. Ibid., 389

48. Ibid. 
law, caught between wanting to de-centre mainstream crisis thinking in international law and desiring to have a voice and broaden perspectives. This shifting, between centre and periphery, between speaking to the mainstream in the hope of change and seeking to prioritize peripheral voices and perspectives haunts the two volumes and, we argue, feminist and critical engagements with international law as a whole. We take this theme up in Chapter 4 of this volume which engages with Kouvo and Pearson's understanding of resistance and compliance as dominant modes of feminist approaches within international law. ${ }^{49}$

As a discipline of crisis, armed conflict has been, and in many aspects still is, understood, studied and narrated as a masculine field. The narrative that armed conflict is strategized, fought and resolved by men paints a picture that can look so natural that it might seem undeserving of questioning. Literature on gender and armed conflict has challenged the framing of armed conflict through men's lives, particularly when the voices of feminists from outside of the global north reflect on modes of resistance and participation in the global south. ${ }^{50}$ Cohn brings together the insight of decades of feminist scholarship and activism which, grounded in women's diverse experiences of conflict, recognizes that gender and conflict are 'mutually constitutive..51 Cohn defines gender as a structural power relation that is inflected through, and co-constituting of, other hierarchical forms of structuring power, such as class, caste, race, ethnicity, age, and sexuality ${ }^{52}$ and that rests on an 'ideology' which, at its root, deems one category (men) as biologically and therefore immutably - more suited for dominant roles. ${ }^{53}$ Referring to the conceptual difference between 'sex' and 'gender', Cohn explains how, at a societal level, a series of characteristics are built for men and women which assign them a significantly larger 'set of differences' than those attributable to biological factors alone. ${ }^{54}$ It is this very set

49. Sari Kouvo and Zoe Pearson, Feminist Perspectives on Contemporary International Law: Between Resistance and Compliance? (Hart Publishing 2011)

50. Marguerite Waller and Jennifer Rycenga (eds), Frontline Feminisms: Women, War, and Resistance (Routledge 2001)

51. Cohn, above note 3,1

52. Cohn, ibid., 5

53. Cohn, ibid., 5, 6; also see Judith Gardam 'An Alien's Encounter with the Law of Armed Conflict' in Ngaire Naffine and Rosemary Owens, Sexing the Subject of Law (Law Book Company 1997) 250

54. Cohn, ibid., 7 
of 'imputed character traits, capacities, strengths, and weaknesses' and their intersection with other systems of power which determine how women and men live and are seen by others before, during and after the conflict. ${ }^{55}$ This reasoning provides us with the analytical tools to challenge a series of stereotypical ideas related to gender and armed conflict such as those that naturally see men involved in active combat roles because of a supposed acceptance and inclination to violence, and women as naturally vulnerable subjects.

Feminists have questioned the classical understanding of conflict and peacetime as neatly separable periods. Women's experience shows how in fact violence can be seen as a 'continuum' crossing conflict and peace-time. ${ }^{56}$ Waller and Rycenga use the image of the frontline to bring together women's accounts of violence crossing what is conventionally understood as peace and conflict, arguing: ' $\mathrm{t}$ ] he frontline is not restricted to military locations', it can be anywhere women fight, in diverse and sometimes contrasting ways, to improve their situation. ${ }^{57}$ The frontline is, according to Waller and Rycenga, 'ubiquitous whether in war, work, or love. ${ }^{58}$ This is shown through diverse examples such as the shedding of light on the hidden violence of home searches in the context of racism-infused police brutality in the US ${ }^{59}$ and the role of women with the Eritrean People's Liberation Front, with the authors paying attention to how such contexts speak to one another ${ }^{60}$ Waller and Rycenga's collection recognizes the diversity of roles that women can assume during armed conflicts through featuring contributions dealing with both nonviolent and not-nonviolent approaches to change. ${ }^{61}$ For

55. Cohn, ibid., 7, 8

56. Cockburn, above note $14,8,44,45$

57. Marguerite Waller and Jennifer Rycenga, 'Introduction' in Marguerite Waller and Jennifer Rycenga (eds), Frontline Feminisms: Women, War, and Resistance (Routledge 2001) xxi

58. Waller and Rycenga, ibid.

59. Nancy Keefe Rhodes, 'Beyond the Baton: How Women's Responses Are Changing Definitions of Police Violence' in Marguerite Waller and Jennifer Rycenga (eds), Frontline Feminisms: Women, War, and Resistance (Routledge 2001)

60. Sondra Hale, 'The Soldier and the State: Post-Liberation Women: The Case of Eritrea' in Marguerite Waller and Jennifer Rycenga (eds), Frontline Feminisms: Women, War, and Resistance (Routledge 2001)

61. Waller and Rycenga, above note 57, xxii 
instance, Shahri, narrating her experience in the National Liberation Army of Iran, gives her account of how women, motivated by a 'need for resistance' progressively became involved in many if not all spheres of the army: ' $[\mathrm{w}]$ hen the era of peaceful political opposition drew to a close, and the need for resistance became apparent, women members of the Mojahedin took on a variety of responsibilities in the bases. ${ }^{62}$ In a different context, but also challenging the idea of the inherent and essentializing peacefulness of women, Svirsky explains how behind the initial idea of the peaceful protest group Women in Black 'was not a woman's natural predilection for peacemaking, but the ideological commitment of women to a vision of international peace [which] did not come from instinct, but from socializing and educating each other over the years. ${ }^{63}$ Both approaches identify women's active choices, as well as a gendered necessity/compulsion to change (rather than some characteristics innate to women), in order to achieve change not only for what they respectively thought was best for other women, but for society more generally.

Noting the differences between us, one of the tools which we have deployed as authors to bring in these differences, situating them as a strength rather than as in opposition to one another, has been to write these volumes collaboratively. While many co-authors write chapters or sections each, taking independent control over their allocated parts, we have chosen to write these books together. From the outset we agreed we should each be able to edit as we wish, the aim being to create one complete text within which no one person can identify what they wrote. This process has not always been easy. Within this text lie numerous tensions and disagreements between us. However, drawing on feminist methods, we have sought to work these tensions into the body of the text, highlighting the different positions we all take, having discussed each of these tensions and worked to ensure that they are represented in a way in which all authors feel content.

62. Sorayya Shahri, 'Women in Command: A Successful Experience in the National Liberation Army of Iran' in Marguerite Waller and Jennifer Rycenga (eds), Frontline Feminisms: Women, War, and Resistance (Routledge 2001) 184

63. Gila Svirsky, 'The Impact of Women in Black in Israel' in Marguerite Waller and Jennifer Rycenga (eds), Frontline Feminisms: Women, War, and Resistance (Routledge 2001) 234, 235 
This is a method which we have drawn on following the participation of three of us in the Feminist International Judgments Project, under which each judgment was written by a chamber or group of several feminist academics. ${ }^{64}$ Collaborative feminist writing as a method to address and embrace difference and as a means to write in plural feminism is thus integral to the text.

Ultimately, we are buoyed by the continuing, enlarging focus on gender and armed conflict that addresses many of the themes of our research. We add to that research through a study of the specific legal regimes that, we argue, gender and conflict might also expand its analysis towards. Prior to commencing our study of the contours of international law on war and peace via a gender analysis, we take stock of the tremendous contribution of gender and feminist scholarship on the women, peace and security agenda inspired by Security Council resolution 1325 and subsequent resolutions. ${ }^{65}$

\section{Security Council resolutions on women, peace and security}

The UN Security Council's thematic resolutions on women, peace and security, ten at the time of writing, have provided key footholds and possibilities for feminist engagement with the work of the Security Council. The adoption of the first Security Council resolution on women, peace and security in 2000, and the nine subsequent resolutions, fuels ongoing feminist discussions, debates and activism reflecting

64. Loveday Hodson and Troy Lavers (eds), Feminist Judgments in International Law (Hart Publishing 2019)

65. Security Council Resolution 1325 (31 October 2000) UN Doc. S/ RES/1325; Security Council Resolution 1820 (19 June 2008) UN Doc. S/RES/ 1820; Security Council Resolution 1888 (30 September 2009) UN Doc. S/RES/ 1888; Security Council Resolution 1889 (5 October 2009) UN Doc. S/ RES/1889; Security Council Resolution 1960 (16 December 2010) UN Doc. S/RES/1960; Security Council Resolution 2106 (24 June 2013) UN Doc. S/ RES/2106; Security Council Resolution 2122 (18 October 2013) UN Doc. S/ RES/2122; Security Council Resolution 2242 (13 October 2015) UN Doc. S/RES/2242; Security Council Resolution 2467 (23 April 2019) UN Doc. S/ RES/2467; Security Council Resolution 2493 (29 October 2019) UN Doc. S/ RES/2493 
many of the tensions within the literature on gender and war. ${ }^{66}$ In the two decades after the adoption of resolution 1325, feminist scholars and activists have taken stock of the merits and the limitations of the women, peace and security agenda, as well as of the risks posed by the institutional capture of feminist debates. ${ }^{67}$

After the conflicts of the 1990s, as well as subsequent reports of widespread sexual violence in the Democratic Republic of the Congo (the Democratic Republic of the Congo (DRC)), there has been a skyrocketing of scholarly, civil society and journalistic interest in women, peace and security. ${ }^{68}$ In response to this emphasis of literature

66. Laura Shepherd, Gender, Violence and Security: Discourse as Practice (Zed Books 2008) chs 5 and 6; Dianne Otto, 'The Security Council's Alliance of Gender Legitimacy: The Symbolic Capital of Resolution 1325' in Hilary Charlesworth and Jean-Marc Coicaud (eds), Fault Lines of International Legitimacy (Cambridge University Press 2010); Amy Barrow, 'UN Security Council Resolutions 1325 and 1820: Constructing Gender in Armed Conflict and International Humanitarian Law' (2010) 92 (877) International Review of the Red Cross 221; Felicity Ruby, 'Security Council Resolution 1325: A Tool for Conflict Prevention?' in Gina Heathcote and Dianne Otto (eds), Rethinking Peacekeeping, Gender Equality and Collective Security (Palgrave Macmillan 2014)

67. Dianne Otto, 'Power and Danger: Feminist Engagement with International Law through the UN Security Council' (2010) 32 Australian Feminist Law Journal 97; Gina Heathcote, 'Feminist Politics and the Use of Force: Theorising Feminist Action and Security Council Resolution 1325' (2011) 7 Socio-Legal Review 23

68. For scholarly accounts, see Sara E Davies and Jacqui True, 'Reframing Conflict-Related Sexual and Gender-Based Violence: Bringing Gender Analysis Back In' (2015) 46 (6) Security Dialogue 495; Nicola Henry, 'Theorizing Wartime Rape: Deconstructing Gender, Sexuality, and Violence' (2016) 30 (1) Gender and Society 44; Elisabeth Jean Wood, 'Conflict-related Sexual Violence and the Policy Implications of Recent Research' (2014) 96 (894) International Review of the Red Cross 457. For an activist/NGO approach, see Oxfam International, Now, the World Is without Me. An Investigation of Sexual Violence in Eastern Democratic Republic of Congo 15 April 2010, Policy Paper available online at: https://www. oxfam.org/en/research/now-world-without-me (accessed December 2019). For journalistic approaches, see Iain Guest, 'Rape in Congo Is Not a Myth If Anything, It Is Under-reported' 21 November 2012, The Guardian https:// www.theguardian.com/commentisfree/2012/nov/21/rape-congo-not-mythunder-reported (accessed December 2019); Will Storr, 'The Rape of Men: The Darkest Secret of War' 17 July 2011 The Observer https://www.theguardian.com/ society/2011/jul/17/the-rape-of-men (accessed December 2019) 
on the women, peace and security agenda and, in particular, on sexual violence, we purposely take a broader approach studying the intersection of gender, war and law beyond the women, peace and security and conflict-related sexual violence agendas. In this section we provide an account of the contours and focus of the various women, peace and security resolutions, commencing with resolution 1325, followed by a review of the five resolutions addressing conflict-related sexual violence, and concluding with an assessment of the four broader resolutions. While we do come back to these tools in the forthcoming chapters, they are not the primary focus of our study. We argue that the centring of the Security Council resolutions on women, peace and security within gender and conflict research has left wider, additionally important legal regimes governing war and peace under-analysed in gender research.

\section{Security Council resolution 1325}

UN Security Council resolution 1325 was unanimously adopted on 31 October 2000. Resolution 1325 is a thematic resolution, a resolution focusing on a broad conflict-related 'theme' as opposed to addressing a situation occurring in a specific country. Its adoption marked the first time the Security Council devoted an entire session to debating women's experiences in conflict and post-conflict situations. ${ }^{69}$ While it is generally understood that Security Council resolutions adopted under Chapter VI of the UN Charter are not legally binding, this approach has been questioned by scholars taking a view based on the ICJ's Namibia Advisory Opinion. ${ }^{70}$ Adopting either view, however, it is difficult to maintain that 1325 is per se a formally legally binding instrument. ${ }^{71}$

69. Carol Cohn, Helen Kinsella and Sheri Gibbings, 'Women, Peace and Security Resolution 1325’ (2004) 6 International Feminist Journal of Politics 130

70. Legal Consequences for States of the Continued Presence of South Africa in Namibia (South West Africa), notwithstanding Security Council Resolution 276 (1970) (Advisory Opinion) [1971] ICJ Rep 16; Rosalyn Higgins, 'The Advisory Opinion on Namibia: Which UN Resolutions Are Binding under Article 25 of the Charter?' (1972) 21 (2) International and Comparative Law Quarterly 270

71. For a contrasting view see Kwadwo Appiagyei-Atua, 'United Nations Security Council Resolution 1325 on Women, Peace, and Security - Is It Binding?' (2011) 18 (3) Human Rights Brief 2 https://digitalcommons.wcl. american.edu/hrbrief/vol18/iss3/1 (accessed December 2019) 
Nevertheless, as O’Rourke shows, feminist activists have proved resourceful in adopting strategies to make the most of resolution 1325 in spite of obstacles caused by its legal profile. ${ }^{72}$ Since its adoption, and despite its status as 'soft' (non-binding) law, Coomaraswamy argues that 'it is hard to think of one resolution that is better known for its name, number, and content. ${ }^{73}$ Otto likewise notes that resolution 1325 proved to be an equally authoritative 'leverage for many grassroots women's groups to claim a role in peace negotiations and postconflict decision making. ${ }^{74}$ Although resolution 1325 has proven a useful tool for feminist activism, it is worth noting that, while 1325 has become a talisman in the realm of gender and conflict research and policy, this remains confined to this specialized realm. There are multiple other resolutions within the mainstream of international legal studies that have received much more attention and traction, which speaks to the marginalization of feminism and gender within the discipline. These resolutions include some of those authorizing the use of force, for example, resolution 1973 which authorized the use of force in Libya. ${ }^{75}$ As such, not only has gender and conflict research centred the resolutions on women, peace and security leaving wider legal regimes under-analysed, this focus has tended to obscure the relative invisibility of women, peace and security within mainstream international legal accounts.

Furthermore, while feminist and women's NGO activism were instrumental in the passing of this first resolution, we are mindful of the challenges connected with entrusting the Security Council 'an undemocratic group, only partially representative of the international community' with the women, peace and security agenda. ${ }^{76}$ Motivated by the will to spur implementation of the Women in Armed Conflict chapter of the 1995 Beijing Platform for Action, NGOs involved in the 1998 Commission on the Status of Women came up with the idea to

72. Catherine O'Rourke, 'Feminist Strategy in International Law: Understanding Its Legal, Normative and Political Dimensions' (2017) 28 (4) European Journal of International Law 1019, 1033-5

73. Radhika Coomaraswamy, Preventing Conflict Transforming Justice Securing the Peace: A Global Study on the Implementation of United Nations Security Council Resolution 1325 (UN Women 2015) 28 https://reliefweb.int/ sites/reliefweb.int/files/resources/UNW-GLOBAL-STUDY-1325-2015.pdf (accessed December 2019)

74. Otto, above note 66,240

75. Security Council Resolution 1973 (17 March 2011) UN Doc. S/RES/1973

76. See Heathcote, above note 67,26 
advocate for a UN Security Council resolution to take up this issue. ${ }^{77}$ These efforts were moved in the context of the Security Council's attempt to regain legitimacy through thematic resolutions in the aftermath of its contested post-Cold War expanding mandate. ${ }^{78}$ Importantly, an NGO Working Group (facilitated by the Women's International League for Peace and Freedom - WILPF) was involved in drafting and setting the ground for the passing of this resolution; but in doing this, they had to come to terms with the constraints linked to inter-state negotiations. In order to present a common position among the Working Group's participants, and to make the proposal more acceptable to states, WILPF had to preventatively accept not to put forward its historical forte of disarmament and anti-militarism. ${ }^{79}$ Then, given that states retain the last word on the content of UN resolutions, the drafting group of NGOs had to accept changes made by states to their initial proposal. ${ }^{80}$ It appears that the opportunity of kickstarting the Security Council women, peace and security framework came at the cost of having to entrust its later development to the discretion and whims of the Security Council's political interests. This point was drawn out in 2019 when the US Trump administration challenged the inclusion of sexual and reproductive health in the women, peace and security framework.

Resolution 1325 urges states to 'ensure increased representation of women at all decision-making levels ... for the prevention, management, and resolution of conflict, ${ }^{81}$ calling also for a gender perspective to be further integrated when thinking through peace agreements and post-conflict reconstruction. ${ }^{82}$ Resolution 1325 has the historical merit of rebalancing the Security Council's approach to women in conflict by emphasizing their active roles in peacemaking. However, this has not been enough to challenge the essentialist approach that, as a result, grants women a seat at the table because of their innate peacefulness. ${ }^{83}$ This approach is not only oblivious to the fact that women assume diverse roles during conflict, including as combatants and perpetrators of violence, it also reinforces the idea that

77. Cohn et al., above note 69,131

78. Otto, above note 66,253

79. Otto, ibid., 255

80. See Ruby, above note 66, 173-84; Otto, above note 66, 261, 262

81. S/RES/1325 paragraph 1

82. S/RES/1325 paragraphs $8,8(a)$

83. Otto, above note $66,256,274$ 
men are inevitably and naturally prone to conflict and violence, which in turn can be used to excuse violence as normal. ${ }^{84}$ In addition, as Cohn notes, '[p] rotecting women in war, and insisting that they have an equal right to participate in the processes and negotiations that end particular wars, both leave war itself in place.85 The war and militarist model of solving disputes remains unchallenged by formal equality strategies that uncritically aim at increasing the number of women within pre-existing structures. Furthermore, the liberal feminist approach visible in resolution 1325 of adding women to traditionally masculine structures fails to understand women's diversity and ends up privileging formal equality over substantive gains. This approach assumes that the similarities among women are more important than their differences (for instance, in terms of class and race). By emphasizing sameness this approach leaves uninterrogated the privilege that allows only certain women to access power through liberal feminist approaches. ${ }^{86}$ Despite these critiques, resolution 1325 has had significant purchase in the transformation of feminist scholarship, policy and activism: influencing the development of a vast discourse that engages different actors and different levels of law as a means to challenge the gendered contours of conflict. Although the most well-known of the Security Council resolutions on women, peace and security it is, in fact, the first of ten resolutions that the Council adopted in the period from 2000 to 2019.

\section{Security Council resolutions on conflict-related sexual violence}

Security Council resolutions 1820 (2008), 1888 (2009), 1960 (2010), 2106 (2013) and 2467 (2019) are characterized by a common focus on conflict-related sexual violence. Four of these resolutions were adopted under either US or UK presidency of the Security Council, while the 2019 resolution was adopted under the presidency of Germany and

84. Ibid.

85. Carol Cohn, 'Mainstreaming Gender in UN Security Policy: A Path to Political Transformation?' in Shirin M Rai and Georgina Waylen (eds), Global Governance: Feminist Perspectives (Palgrave Macmillan 2008) 198 (emphasis in the original)

86. Gina Heathcote, 'Security Council Resolution 2242 on Women, Peace and Security: Progressive Gains or Dangerous Development?' (2018) 32 (4) Global Society 377, 378 
attracted significant opposition from the US, China and Russia. ${ }^{87}$ Feminist critique has observed how the focus on sexual violence works to restrict the wider approach that was present in resolution 1325 to a narrow emphasis on sexual violence, which risks overshadowing other kinds of gender-related harms connected to conflict, as well as women's initiatives for peace. ${ }^{88}$

Resolution 1820, the first of this set of resolutions, notes that 'women and girls are particularly targeted by the use of sexual violence, including as a tactic of war. ${ }^{89}$ Significantly, this resolution links conflictrelated sexual violence with peace and security. First, the Security Council 'expresses its readiness ... to ... adopt appropriate steps to address widespread or systematic sexual violence' since it, under specific circumstances, 'may impede the restoration of international peace and security. ${ }^{90}$ Second, it states that 'steps to prevent and respond to such acts' can instead 'significantly contribute to the maintenance of international peace and security. ${ }^{91}$ This can be seen as related to the tendency to expand the category of threats to the peace. Furthermore, the language of maintaining and restoring international peace and security directly echoes the wording of Article 39 and Article 42 of Chapter VII of the UN Charter. Therefore, through this language, resolution 1820 seems to be setting the ground for the possibility of deploying force to 'save women. ${ }^{\text {'2 }}$ Missing in this account is a gender analysis of how force is legally justified and/or authorized.

Resolution 1888 mainly echoes 1820 starting from restating the connection between sexual violence and peace and security. ${ }^{93}$ This resolution provided the basis for the establishment of specific figures including the UN Special Representative of the Secretary General on sexual violence in conflict. $^{94}$ While resolution 1960 presents

87. What's in Blue, 'In Hindsight: Negotiations on Resolution 2467 on Sexual Violence in Conflict' 2 May 2019, What's in Blue https://www. whatsinblue.org/2019/05/in-hindsight-negotiations-on-resolution-2467-onsexual-violence-in-conflict.php (accessed December 2019)

88. Gina Heathcote, above note 86,380

89. S/RES/1820 preamble

90. S/RES/1820 paragraph 1

91. S/RES/1820 paragraph 1

92. Gina Heathcote, The Law on the Use of Force: A Feminist Analysis (Routledge 2012) 50, 51

93. S/RES/1888 paragraph 1

94. S/RES/1888 paragraphs 4,8 
many aspects of 1325, 1820 and 1888, paragraph 3 of resolution 1960 establishes a 'naming and shaming mechanism' as a way to operationalize implementation of the previous resolutions. ${ }^{95}$ Feminist analysis has highlighted the limits of this provision due to its narrowness in adopting naming and shaming as a response to sexual violence rather than more sophisticated strategies tackling 'the nexus between harmful understandings of gender difference that contribute to the prevalence of, and impunity for, sexual violence globally in both conflict and nonconflict communities. ${ }^{36}$ This kind of response originates in the Security Council's responsiveness to US radical feminist approaches and a focus on sexual harm which obscures deeper intersectional understandings of conflict-related harm. In doing so, the Security Council, rather than putting at the centre of its analysis the experiences and needs of women in conflict and post-conflict situations, reflects the presumptions and ideas that many global north (gender) analysts retain and, as a result, it is set to fail to bring about significant change. ${ }^{97}$

Different from the previous resolutions, Security Council resolution 2106 was preceded by the April 2013 G8 Declaration on Preventing Sexual Violence in Conflict, an initiative led by the UK. ${ }^{98}$ The G8 Declaration touches upon different aspects of conflict-related sexual violence, such as the rehabilitation of victims and the recognition of the need for better protection for human rights defenders, but largely focuses on the lack of accountability for sex-related crimes during armed conflict. This initiative paved the way for resolution 2106 which was adopted under the UK's presidency of the Security Council. Resolution 2106 reiterates the call for the implementation of previous resolutions. The participation aspect is not completely absent from this resolution, but it centres participation in the field of sexual violence prevention. ${ }^{99}$

95. S/RES/1960 paragraph 3; Gina Heathcote, 'Naming and Shaming: Human Rights Accountability in Security Council Resolution 1960 (2010) on Women, Peace and Security' (2012) 4 (1) Journal of Human Rights Practice 82-105

96. Heathcote, above note 95,86

97. Heathcote, above note $95,87,88$

98. Declaration on Preventing Sexual Violence in Conflict (11 April 2013) https:/www.gov.uk/government/uploads/system/uploads/attachment_data/ file/185008/G8_PSVI_Declaration_-_FINAL.pdf (accessed December 2019)

99. For instance, the first paragraph of resolution 2106 retraces the wording of paragraph 1 in resolutions 1820, 1888 and 1960, but here the paragraph's concluding sentence is replaced by the Security Council stressing 'women's participation as essential to any prevention and protection response. But see also paragraphs 5, 16 
This reflects what Heathcote has identified as 'a protective participation model' which can undermine the complexity of women's experiences in armed conflict. ${ }^{100}$ As such, the over-emphasis on sexual violence in these resolutions has been criticized for being narrow and reductive. Not only does it reflect just one strand of feminist thought - US radical feminism - but it also focuses on only one of the four pillars initially envisaged in resolution $1325 .{ }^{101}$ This has the effect of putting women as victims of sexual violence at the centre-stage of international attention while linking the possibility of the use of force to rescue women from it. ${ }^{102}$ Throughout these two volumes our goal is to look beyond this framing to engage law's authorizing and justifying, regulating and prosecuting, armed conflict and post-conflict under international law.

The fifth resolution on conflict-related sexual violence, resolution 2467 , demonstrates further the risks of engaging the Security Council, ultimately an unrepresentative and unaccountable political institution with the capacity to make law, to bring forward an agenda on gender and conflict. Germany's initiative as president of the Council was to propose a draft for 2467 that incorporated a wider understanding of victim-survivor needs in post-conflict communities, including addressing sexual and reproductive health in post-conflict communities. However, the conservative US administration, under the Presidency of Donald Trump, refused to support the drawing in of sexual and reproductive health due to a fear of abortion rights being expanded. In the end, agreed language on sexual and reproductive health from resolution 2106 proved to be unacceptable to the US administration and was redacted from the draft as a way to secure US support for the resolution. ${ }^{103}$ Furthermore, both China and Russia abstained from voting even in spite of the concessions on the proposed expanded role on sexual violence in conflict to be assigned to the Informal Expert Group on Women, Peace and Security (mentioned below). The final text of the resolution does focus on victims and survivors, including

100. Gina Heathcote, 'Participation, Gender and Society' in Gina Heathcote and Dianne Otto (eds), Rethinking Peacekeeping, Gender Equality and Collective Security (Palgrave Macmillan 2014) 48-69

101. Heathcote, above note 95, 93, 94; Nicola Lacey, 'Feminist Legal Theory and the Rights of Women' in Karen Knop (ed), Gender and Human Rights (Oxford University Press 2004) 23-4

102. Heathcote, above note 67,20

103. What's in Blue, above note 87 
male victims, but has been described as 'overly simplistic and [as failing] to recognize that conflict-related sexual violence is itself an expression of masculinity and dominance.104 While not devoid of significance, we argue that these debates have occupied feminist scholars working in the field of gender and conflict at the cost of other, important legal and political engagements.

\section{Security Council resolutions 1889, 2122, 2242 and 2493}

In general, resolutions 1889 (2009), 2122 (2013), 2242 (2015) and 2493 (2019) have taken a broader approach to women, peace and security than those discussed in the previous section. In contrast to the group of resolutions focused on conflict-related sexual violence, these resolutions have been adopted under, respectively, Vietnamese, Azeri, Spanish and South African presidencies of the Security Council. Resolution 1889, started building 'a model of substantive participation' for the women, peace and security agenda. ${ }^{105}$ Resolution 1889 acknowledges that 'women in situations of armed conflict and post-conflict situations continue to be often considered as victims and not as actors in addressing and resolving situations of armed conflict ${ }^{106}$ and is attentive to the socio-economic dimension in post-conflict and peacebuilding. ${ }^{107}$ However, it took until the seventh women, peace and security resolution, resolution 2122 , to find evidence of recognition of diversity among women in the text of the resolutions. In a passing, yet significant, mention the resolution ' $r$ r] equests the Secretary-General's Special Envoys and Special Representatives to United Nations missions, from early on in their deployment, to regularly consult with women's organizations and women leaders, including socially and/or economically excluded groups of women. ${ }^{108}$ While this paragraph is not directed at UN member states and it is therefore circumscribed in its scope, as Heathcote notes 'the language of consulting diverse groups of women ... is of considerable importance and presents an opening for women who feel unrepresented within international

104. 'UN Security Council Adopts Resolution 2467' (2019) Global Justice Center http://globaljusticecenter.net/press-center/press-releases/1117-unsecurity-council-adopts-resolution-2467 (accessed December 2019)

105. Heathcote, above note 86,380

106. S/RES/1889 preamble

107. S/RES/1889 paragraphs $1,10,15$

108. S/RES/2122 paragraph 7(a) (emphasis added) 
security discourse. ${ }^{109}$ Ultimately, however, resolution 2122, like its predecessors, fails to recognize 'women's mobilisation for peace ... as security work.'110

The preamble of resolution 2122 does acknowledge the adoption of the Arms Trade Treaty (ATT). Although addressed in a limited manner and only in relation to the ATT (which deals only with issues of the arms trade and not general disarmament), in recognizing the ATT resolution 2122 can be seen as an entry point for future discussion and advocacy on disarmament. Furthermore, through resolution 2122 the Security Council requested the Secretary General to commission the Global Study on the implementation of resolution 1325 ahead of the fifteenth year since the adoption of that resolution, which led to the adoption of resolution 2242 with increased input of feminist and women's NGOs. ${ }^{111}$

Resolution 2242 (2015) was adopted in the context of the stocktaking exercise that marked the fifteenth anniversary of the adoption of resolution 1325. For the first time, the Security Council agreed on a substantive decision: in paragraph 5(b) the Council '[d]ecides to integrate women, peace and security concerns across all countryspecific situations on the Security Council's agenda.. ${ }^{112}$ While this language is qualified by the notion of 'taking into account the specific context of each country', this formulation is fairly unequivocal in its intent and has the characteristics to bind the Council itself for future action. In the next chapter we undertake an evaluation of this decision with respect to Syria and show that the Security Council in that respect failed to adhere to its own commitments. Following resolution 2242 the Informal Experts Group on Women, Peace and Security was instituted in 2016. The group was created 'to facilitate a more systematic approach to Women, Peace and Security within [the] work [of the Council] and enable greater oversight and coordination of implementation efforts. ${ }^{113}$ More research is needed at this stage to establish whether this group has achieved substantive results in changing the approach to women, peace and security.

The existence of women who participate in combat or commit crimes has received limited representation within the Security Council's women, peace and security framework where the image of women

109. Heathcote, above note 86,381

110. Heathcote, ibid., 382

111. S/RES/2122 paragraph 16

112. S/RES/2242 paragraph $5(\mathrm{~b})$

113. S/RES/2242 paragraph 5(a) 
as victims has comparatively retained primacy. While resolution 2242 mentions the need to conduct research on what leads to the radicalization of women - therefore admitting that women can be involved in extremism and terrorism - it also suggests that women's participation in extremism is not entirely voluntary, but rather it is the result of 'drivers' specific to women. ${ }^{114}$ This approach reiterates the assumption that - for women - to participate in extremism, terrorism or indeed violence, there must be a reason that is in some way connected to their gender. However, women's reasons for participating in violent extremism are often similar to men's. Sjoberg and Gentry highlight how the field of terrorism studies has tended to see the women who participate in violence as a result of extremist views as a product of women's maternal and nurturing characteristics. ${ }^{115}$ This means that women's 'innate' ability to nurture is seen as so powerful it even extends to participating in terrorism, if only for the need to be needed. Not only does this understanding limit women's ability to be agents in their own lives, but it reaffirms stereotypical characteristics as inevitable. Therefore, while resolution 2242 presents some advances in terms of openings to recognition of differences among women and attention to 'gender perspectives, ${ }^{116}$ the juxtaposing of the anti-terrorism and women, peace and security agenda presents the risk of the latter 'being co-opted into the civilising tropes that surround the work of countering terrorism and violent extremism. ${ }^{117}$ As explained by Ní Aoláin, this 'does not mean that women will be included in defining what constitutes terrorism, women are more likely to be added to pre-existing counterterrorism frameworks (notoriously shaped in a non-feminist way) that would be strengthened through improved gender legitimacy, in turn resulting in women, peace and security 'becoming harnessed to the pursuit of broader military and ideological goals. ${ }^{3} 18$

114. S/RES/2242 paragraph 12

115. Laura Sjoberg and Caron E Gentry, Mothers, Monsters, Whores: Women's Violence in Global Politics (Zed Books 2007) 33

116. Heathcote, above note 86,385

117. Heathcote, above note 86,387

118. Fionnuala Ní Aoláin, 'The "War on Terror" and Extremism: Assessing the Relevance of the Women, Peace and Security Agenda' (2016) 92 (2) International Affairs 276, 278 
The most recent Security Council resolution, 2493, is a general resolution that is focused on mobilizing a renewed pledge from states and international institutions in implementing the women, peace and security agenda. While making some references to women's participation in peace talks and in mechanisms to monitor peace agreements (including 'context-specific approaches'), ${ }^{119}$ resolution 2493 remains a rather unambitious text. One of the bars to more progressive provisions seemed to have been the continuing controversy over the inclusion of language on sexual and reproductive health that had already characterized the adoption of resolution 2467. After the adoption of 2493, the US Ambassador to the UN stated that the US 'cannot accept references to sexual and reproductive health or any references to safe termination of pregnancy or language that would promote abortion or suggest a right to abortion. ${ }^{120}$

Positive and negative impacts of the women, peace and security agenda

The women, peace and security agenda presents evidence of a problem that, in another UN context, has been identified as 'ritualism. ${ }^{121}$ Namely, a posture where the Security Council produces resolutions and reports of activities while retaining 'an indifference to or even reluctance' to actually bringing about significant change. ${ }^{122}$ This is a problem that O'Rourke and Swaine note, with respect to new women, peace and security resolutions often featuring provisions that are mainly directed at the UN system or merely reiterative of previous women, peace and security language, allowing states to claim they are 'doing something'

119. S/RES/2493 paragraphs 3,9 (a)

120. Record of the 8649th meeting of the UN Security Council (29 October 2019) UN Doc. S/PV.8649, remarks of US Ambassador Kelly Craft; Michelle Nichols, 'U.S. Pitted against Britain, France, South Africa, Others at UN over Abortion' Reuters 29 October 2019 https://www.reuters.com/article/ us-women-rights-usa-un/us-pitted-against-britain-france-south-africaothers-at-un-over-abortion-idUSKBN1X829K (accessed December 2019)

121. Hilary Charlesworth and Emma Larking, 'Introduction: The Regulatory Power of the Universal Periodic Review' in Hilary Charlesworth and Emma Larking (eds), Human Rights and the Universal Periodic Review: Rituals and Ritualism (Cambridge University Press 2015) 10, 21

122. Ibid., 10 
while doing very little. ${ }^{123}$ This tendency seems to be the natural evolution of what Otto, at the time of the inception of the women, peace and security agenda, had identified as the Security Council's attempt to regain legitimacy through gender after its shortcomings in facing the humanitarian crises of the 1990s. ${ }^{124}$ Evidence of gender ritualism can also be found in the fact that women, peace and security language remains confined to thematic resolutions (considered a 'softer' area of work), with the Council seemingly being reluctant to seriously consider women, peace and security concerns in country-specific resolutions, or as Ní Aoláin has observed, in new wars contexts. ${ }^{25}$

At the same time, as noted above, there is a tension for feminists with working with/in the Security Council. Thus, while the lack of reference to women, peace and security in binding Security Council measures can be seen as a problem of enforceability on the one hand, on the other, the actual use of women, peace and security as a binding mechanism would be problematic, potentially exacerbating the core issues around representation and intersectionality, the hypervisibility of sexual violence and masking the other silences in the agenda. ${ }^{126}$ Rather than advancing a policy point about the content of country-situation resolutions, we are concerned with highlighting the absence of women, peace and security from certain areas of the Council's work because it is symptomatic of the permanence of a gendered bias in the functioning of the institution. Highlighting the Security Council's failure to follow through with its own decision on women, peace and security - while at the same time resisting understandings of use of force as a solution to complex socio-economic-politico-cultural problems - further helps us to question, once again, the appropriateness of the Security Council as a site for progressive work on gender and conflict.

So far feminist engagement through the women, peace and security agenda has not been successful in delivering a fundamental change in the logics and power structures of the Security Council. On the contrary,

123. Catherine O'Rourke and Aisling Swaine, 'CEDAW and the Security Council: Enhancing Women's Rights in Conflict' (2018) 67 International and Comparative Law Quarterly 167, 182

124. Otto, above note 66,240

125. Ní Aoláin, above note 118, 277; Mary Kaldor, New and Old Wars: Organized Violence in a Global Era (Polity Press 1999)

126. Dianne Otto, 'Women, Peace and Security: A Critical Analysis of the Security Council's Vision' in Fionnuala Ní Aoláin et al. (eds), The Oxford Handbook of Gender and Conflict (Oxford University Press 2018) 105-18 
Otto shows how long-standing feminist agendas on disarmament and militarism had to be dropped while the Council gained a share of 'gender legitimacy.' ${ }^{127}$ While resolution 2122, as noted above, does mention disarmament, thus nodding to the feminist activism behind much of the women, peace and security agenda, it does so only in reference to the ATT which is much less about general disarmament and is, rather, about the arms trade and ensuring that arms do not get into the hands of the 'wrong people. ${ }^{128}$ Stavrianakis observed how in the ATT 'language and regulatory bureaucratic practices of risk assessment are embedded in Western, liberal regimes.' ${ }^{129}$ The ATT also risks legitimating particular types of arms trade through law by giving the impression that arms trade can be 'ethical' as opposed to seeking to removing arms trade all together. This argument can be linked to the wider critique of how international humanitarian law, in its attempt to 'humanize' war, has also fostered the idea of the possibility of 'humane' wars. We explore this argument in Chapter 4. It is therefore interesting that the moment when the women, peace and security resolutions do finally mention disarmament - despite disarmament having been core in the feminist lobbying on women, peace and security well before 1325 - refers to the ATT as opposed to, for example, the question of the ethics of making, selling and using arms at all.

The problems with the women, peace and security agenda have led scholars such as Kapur to state that the agenda is an expression of

127. Dianne Otto, 'Contesting Feminism's Institutional Doubles: Troubling the Security Council's Woman, Peace and Security Agenda' in Halley et al. (eds), Governance Feminism: Notes from the Field (University of Minnesota Press 2019) 200-29. To note, while the word 'disarmament' is mentioned in paragraph 13 of resolution 1325, this refers to programmes of disarmament, demobilization and reintegration of former combatants

128. Otto, above note 126

129. Anna Stavrianakis, 'Legitimising Liberal Militarism: Politics, Law and War in the Arms Trade Treaty' (2016) 37 (5) Third World Quarterly 845; Cooper states: 'Arms control as governmentality denotes a context where mechanisms of proscription and permission operate as technologies of social control designed to manage which populations can legitimately use what kinds of weapons.' Neil Cooper, 'Race, Sovereignty, and Free Trade: Arms Trade Regulation and Humanitarian Arms Control in the Age of Empire' (2018) 3 (4) Journal of Global Security Studies 445 (emphasis in the original) 
what Halley terms 'governance feminism. ${ }^{130}$ The women, peace and security resolutions - with their emphasis on women as victims or peaceful agents who require representation - present a largely radical or liberal feminist version of feminism. It is these versions of feminism which the Security Council and other international legal standardsetting institutions have embraced the most, often even turning these already limited viewpoints on feminism into 'shadowy versions' of themselves. ${ }^{131}$ In this understanding, women's active participation in armed conflict or in igniting revolt and armed action is dismissed as minor and as a deviation from the 'normal' role of women. Through such narratives of inclusion and exclusion, gendered and essentializing stereotypes about both men and women are upheld. Importantly, these understandings leave uninterrogated the association of war and violence with masculinity and the idea of a violent response as effective in times of crisis. The wider causes of insecurity are also left untouched by these discussions.

Kapur states that there is a need to understand women's experiences on the peripheries as a method to challenge the normative assumptions that inform gender and sexuality discourses within law. ${ }^{132}$ Kapur's discussion of the 'authentic victim subject' highlights the tendency for international women's rights movements to focus on a particular ideal of the 'Third World woman', which excludes the existence of localized or personal everyday harms and rather focuses solely on women's experience of sexual violence in armed conflict. ${ }^{133}$ The importance of identifying the hypervisibility of women as victims of sexual violence in armed conflict reaffirms the need to see women in armed conflict as having crucial knowledge on peacebuilding that disrupts both victimhood and the perception that women's insecurity post-conflict is merely a result of harmful cultural practices. Rather, there needs to be greater interrogation of social, political and economic structures that create sites of precarity before, during and after conflict.

While remaining critical of the women, peace and security agenda, we are also wary of dismissing the agenda as merely an expression of

130. Ratna Kapur, Gender, Alterity and Human Rights: Freedom in a Fishbowl (Edward Elgar 2018) 104

131. Otto, above note 127, 203, referring to Nancy Fraser, 'Feminism, Capitalism and the Cunning of History' (2009) 56 New Left Review 97

132. Kapur, above note 12, 131

133. Kapur, ibid., 115 
governance feminism, as to do so risks erasing the framework's origins in women's peace activism. As mentioned above, one of the oftenhailed outcomes of the resolutions has been their use as an instrument in local projects for inclusion of women in peace agreements and post-conflict institutions. ${ }^{134}$ This has had, however, both positive and negative impacts. For example, while funding has been funnelled through the women, peace and security agenda supporting feminist grassroots groups, these groups have also noted that, since resolution 2242 and the focus on counter-terrorism, much of the funding for grass-roots feminist groups working on conflict-related issues is now also tethered to combatting terrorism, which narrows down the focus of such groups and forces them to work on issues which they do not necessarily believe are of priority. ${ }^{135}$ An example of the mixed impact of the agenda can be seen when looking at the aftermath of the internal armed conflict in Nepal (1996-2006). Some Nepali women's organizations used resolution 1325 to lobby the UN to uphold the resolution's standards during its work in Nepal and to support the campaign for inclusion of diverse women in the peace process. ${ }^{136} \mathrm{After}$ the conflict ended however, Sthapit and Doneys have observed the lack of substantive change for rural women in Nepal. In their field research with former female combatants of the People's Liberation Army (PLA), Sthapit and Doneys have found how for these women 'the ground reality remains unchanged.' ${ }^{137}$ In the words of one of the combatants: 'These [resolutions] are for the high-ranking fighters and leaders and richer people, for us it makes no difference. We have not felt it trickling down to us, yet.' ${ }^{\text {'138 }}$ This 2012 statement clearly highlights how the

134. Otto, above note 67,105

135. Sophie Giscard d'Estaing 'Engaging Women in Countering Violent Extremism: Avoiding Instrumentalisation and Furthering Agency' (2017) 25 (1) Gender and Development, 103, 115

136. Open letter from Women Peace Alliance, PEWA to Mr. Ian Martin, Personal Envoy of the UN Secretary General to Nepal for inclusive, proportionate representation and women sensitive peace process, 12 December 2006 https://www.nepalresearch.com/crisis_solution/papers/pewa_061212.pdf (accessed December 2019)

137. Lorina Sthapit and Philippe Doneys, 'Female Maoist Combatants during and after the People's War' in Åshild Kolås (ed), Women, Peace and Security in Nepal: From Civil War to Post-Conflict Reconstruction (Special Nepal Edition, Routledge 2018) 43

138. Ibid. 
resolutions risk remaining superficial instruments if not accompanied by broader intersectional change, for instance, in the reduction of economic inequality and of the divide between rural and urban Nepal. Incidentally, this is a further clue that encourages us to look beyond law to achieve transformative change. The remarks on 1325 expressed by former female PLA combatants are not surprising if seen in the light of long-standing criticism advanced by Tamang of how foreign development donors were key in creating the figure of 'an essentialized "Nepali woman"' as a 'single over-arching category' and 'homogenized and agency-less' individual. ${ }^{139}$ Contextualized in this way, the women, peace and security agenda appears as yet another essentializing western instrument that serves limited inclusion purposes for women from conflict-affected countries. Apart from the timid and belated reference to women's diversity in resolution 2122 , the women, peace and security resolutions have not done much to avoid this criticism.

Despite the vast amounts of space and resources dedicated to women, peace and security, 'the continued silence about homophobic and transphobic violence targeting lesbian, gay, bisexual, transgender and queer (LGBTQ) individuals in conflict-related environments is alarming. ${ }^{140}$ Focusing on sexual and gender-based violence, Hagen critiques the "heteronormative assumptions in the framing of the [women, peace and security] agenda, ${ }^{141}$ noting how 'gender' is often equated to 'women', silencing the experiences of queer survivors of sexual and gender-based violence. ${ }^{142}$ This heteronormative focus on women as the paradigm victims and men as the paradigm perpetrators has also been critiqued by Paige when analysing Security Council debates generally (i.e. not just the women, peace and security agenda) highlighting how the lack of focus on queer subjects is prevalent

139. Seira Tamang, 'The Politics of Conflict and Difference or the Difference of Conflict in Politics: The Women's Movement in Nepal' (2009) 91 Feminist Review 61, 65, 66

140. Jamie J Hagen, 'Queering Women, Peace and Security' (2016) 92 (2) International Affairs 313

141. Ibid.

142. Ibid., 318 
throughout collective security frameworks. ${ }^{143}$ Furthermore, as Hamzić shows, where LGBT $^{144}$ subjects are seen within collective security, this is often done through a standard of civilization lens, with the killing of LGBT people by ISIS, for example, being used by the Security Council to highlight the barbarianism of the Islamic 'other.' ${ }^{145}$

The narrow, heteronormative framing of gender within collective security and women, peace and security, however, is problematic not only in terms of which subjects it excludes but also in terms of where gendered voices are visibilized. While the women, peace and security framework remit centres issues such as sexual violence and women's participation, discussions on military technologies, on authorizations for the use of force or the mandate for Security Council authorized missions occur in the Security Council and other international institutions without examination of the gendered contours of these debates. While this lack of focus may be justified, at one level, through the idea that the women, peace and security framework focuses on women's lives, such an argument ignores the gendered impact of military technologies, from the role of gender identification in targeting decisions to the biases present in the use and design of all technologies. ${ }^{146}$ At the same time, the spaces in which these technologies are discussed tend to then ignore gender as a useful analytical framework altogether, gender once again being seen as about women as victims or their numeric representation. This is despite the fact that gender provides an extremely useful analytical tool through which to think through

143. Tamsin Phillipa Paige, 'The Maintenance of International Peace and Security Heteronormativity' in Dianne Otto (ed), Queering International Law: Possibilities, Alliances, Complicities, Risks (Routledge 2018)

144. The use of LGBT here reflects the Security Council's own framing; see above note 35

145. Vanja Hamzić, 'International Law as Violence: Competing Absences of the Other' in Dianne Otto (ed), Queering International Law: Possibilities, Alliances, Complicities, Risks (Routledge 2018)

146. Lauren Wilcox, 'Embodying Algorithmic War: Gender, Race, and the Posthuman in Drone Warfare' (2017) 48 (1) Security Dialogue 11; Lorna McGregor, Daragh Murray and Vivian Ng, 'International Human Rights Law as a Framework for Algorithmic Accountability’ (2019) 68 (2) International and Comparative Law Quarterly 309 
these issues. ${ }^{147}$ The framing of collective security thus binds the women, peace and security agenda to a limited account of gendered approaches to conflict, not only in terms of the conflict-affected subjects it excludes, but also in terms of topics, perpetuating the idea that gender is about sexual violence and participation alone. Women, peace and security, for example, could look extremely different if it were to include feminist perspectives on military technologies, from experiences of living under drones, ${ }^{148}$ to the consideration of the ways in which data collection is used post-conflict to invisibilize men of colour as refugees when it comes to resource distribution and aid, ${ }^{149}$ to noting the ways in which military technologies are used to uphold and perpetuate gendered, racialized, ableist and humanist norms. ${ }^{150}$

After examining the Security Council women, peace and security framework, it appears that while it has opened opportunities, it also presents serious limitations and challenges. Many of these are connected to the Security Council shaping discourse and policy on women and gender in conflict and post-conflict situations. Importantly, we believe feminist analysts and activist attention on legal and institutional instruments on gender and conflict should not be limited to this forum. This book, noting that much work on gender and conflict since 1325 has been framed in terms of women, peace and security, seeks to move beyond the agenda, taking feminist methodologies as the central point through which to think about gender and conflict as opposed to the women, peace and security agenda and thereby situating feminists as the central voice on gender and conflict as opposed to the Security Council. While we are aware that in outlining the women, peace and security agenda in this introduction we have, already, in some ways centred the agenda in this book, we have done this more to outline the

147. Emily Jones, Sara Kendall and Yoriko Otomo, 'Gender, War and Technology: Peace and Armed Conflict in the 21st Century' (2018) 44 (1) Australian Feminist Law Journal 1

148. Helene Kazan, 'The Architecture of Slow, Structural, and Spectacular Violence and the Poetic Testimony of War' (2018) 44 (1) Australian Feminist Law Journal 119

149. Kristin Sandvik, 'Technology, Dead Male Bodies, and Feminist Recognition: Gendering ICT Harm Theory' (2018) 44 (1) Australian Feminist Law Journal 49

150. Gina Heathcote, 'War's Perpetuity: Disabled Bodies of War and the Exoskeleton of Equality' (2018) 44 (1) Australian Feminist Law Journal 71 
inclusions and exclusions from the start to allow us, as authors, to move beyond the agenda throughout the rest of the text.

\section{Introduction to Volume One}

This book analyses areas of international law focused on armed conflict including the jus ad bellum, the collective security structure and the international humanitarian law of armed conflict, alongside an account of counter-terrorism and countering violent extremism in peacetime states and the everyday, lived realities of insecurity within those states. The final chapter examines international criminal law to think about the role of law and the claim of shifting from armed conflict towards peace through prosecutions. Throughout the text we continue to analyse and draw in the women, peace and security framework. Nevertheless, our primary focus is the international laws on armed conflict, its regulation, authorization and consequences, and the laws governing the transition to peace. Throughout we examine the impact of the laws on armed conflict on states experiencing conflict, peacetime and post-conflict states to disrupt the assumption of war and peace as geographically and temporally distinct experiences.

Chapter 1 uses gender theories to examine the potential and the limitations of collective security structures. The chapter commences with an introduction to the collective security system. That is, the role of the UN Security Council and its powers under Chapter VI and Chapter VII of the UN Charter. To analyse the placing of militarized enforcement measures at the apex of international law, the chapter engages an account of law and violence to illuminate law's persistent violence as well as the conundrum of using military force to halt military force. The chapter reviews the Security Council's resolutions in response to the conflict in Syria since 2011 to demonstrate the limited impact of the women, peace and security agenda and the troubled positioning of feminist approaches within the work of the Security Council. As such, we interrogate the consequences of supporting the work of the Security Council via the women, peace and security framework. The use of and the failure to authorize military intervention raise important, unanswered questions for feminist scholars. The chapter concludes that feminist activism needs to provide wider, and deeper, analysis of the range of collective security endeavours that are bolstered by the institutional turn to the Security Council via the women, peace and security agenda. 
Chapter 2 introduces the mechanisms that states use to justify the use of military force, in particular, international law on self-defence and humanitarian intervention, as well as state arguments for the protection of nationals abroad and the use of force with the consent of the host state. The chapter commences with an introduction to these unilateral justifications for military force. The chapter also introduces existing feminist scholarship, largely structural bias feminisms, on unilateral force. The chapter offers an analysis of two forms of unilateral force: self-defence and humanitarian intervention. The chapter argues that the analysis of unilateral force would benefit from further structural bias feminist analyses while also calling for the development of intersectional feminist methods. This approach incorporates the space to analyse gendered livelihoods as well as macro dimensions of power that inform the structures, institutions and contours of international law. The study of power relations, via an intersectional feminist commitment, challenges macro-level manifestations of power and inequality that stem from the everyday to the international. We argue that unilateral force undertaken by states outside of the collective security system is a manifestation of gendered power relations and ultimately distracts scholars from the consequences and lived insecurities that stem from military force, whether justified, authorized or illegal.

Chapter 3, on countering terrorism, identifies the increased convergence of women and counter-terrorism agendas in the work of the Security Council and traces the gendered effects into the domestic policy of states, including peacetime states. The chapter draws in queer perspectives on terrorism, feminist work on everyday violence in the war on terror and postcolonial feminist perspectives to analyse the impact of counter-terrorism laws. The chapter analyses the means through which gender, sexuality, race and Islamophobia, among other factors such as class, play out in the biopolitical and necropolitical ordering of life through law in the era of counter-terrorism. ${ }^{151}$ The chapter identifies

151. Necropolitics is a concept coined by Mbembe to indicate the 'contemporary forms of subjugation of life to the power of death' in Achille Mbembe, 'Necropolitics' (2003) 15 (1) Public Culture 39. Necropolitics has been understood by Allinson as 'the arrogation of ... the sovereign's command of death, but within the apparatuses of surveillance, auditing, and management which characterize "biopower"', Jamie Allinson, 'The Necropolitics of Drones' (2015) 9 International Political Sociology 114 
the lack of focus from feminist and gender theorists on the attrition of international law, particularly international humanitarian law and human rights laws in the era of global war against terrorism. Furthermore, we identify lawfare, that is, the use of the law to justify military force, in counter-terrorism agendas as of interest to future feminist accounts. ${ }^{152}$ Throughout Chapter 3 we examine the placement of counter-terrorism strategies at the margins of legality, while impacting most directly on racialized, queer and classed subjects. ${ }^{153}$ Through the analysis of UK and French counter-terrorism laws we complicate the assumption that peace and conflict are distinct experiences, demonstrating how peacetime states have used counter-terrorism agendas to produce insecurities.

Chapter 4 offers a feminist analysis of the international humanitarian laws of armed conflict. Through providing an analysis of the Geneva Conventions (including the Additional Protocols) and the Hague Conventions, the chapter draws in existing feminist scholarship on the gendered contours, and effects, of the regulation of the methods and means of armed conflict and attempts at humanitarian constraints on military activities. We identify how discourses of victimization and protection develop within the law as though they are inevitable elements of an armed conflict. The chapter offers a more complex version of wartime subjectivities that seeks to disrupt the heteronormativity of the gender binary that is embedded in international humanitarian law. The chapter problematizes the framework of international humanitarian law identifying the acceptance of the inevitability of armed conflict as troubling for feminist approaches, such that existing feminist analysis of the tensions between resistance and compliance within critical feminist projects are drawn on. The chapter concludes by arguing that the gender binary sits not only in the foundations of international humanitarian law of armed conflict but also that a sole focus on this binary risks ignoring new developments on the battlefield, from new wars and asymmetrical conflicts to the development of new forms of military technologies. The chapter concludes with a call for

152. Eyal Weizman, 'Legislative Attack' (2010) 27 (6) Theory, Culture and Society 11; David Kennedy, 'Lawfare and Warfare' in James Crawford and Martti Koskenniemi (eds), The Cambridge Companion to International Law (Cambridge University Press 2012) 158

153. Jasbir K Puar, Terrorist Assemblages: Homonationalism in Queer Times (Duke University Press 2007) 
posthuman feminist understandings that keep abreast of and challenge feminist thinking beyond the gendered narratives of victimization and protection. This is a theme that re-emerges in Volume Two in our study of military technologies and their capacity to traverse the war and peace dichotomy, re-directing a focus and funds from tackling (gendered) harms and re-producing insecurity in new forms.

The analysis of international criminal law provides the focus of Chapter 5. This chapter introduces the history of international criminal law, in the Nuremberg and Tokyo tribunals, the development of the ad hoc tribunals, hybrid courts and the International Criminal Court as an entry into our analysis of international criminal law. We argue that even with the gender law reforms that are apparent from the 1990s, these foundations constrain the scope and possibilities of international criminal law. Following the account of international humanitarian law and the production of gendered victims through legal regulation, this chapter identifies the hypervisibility of crimes of sexual violence against women in international criminal law. This is contrasted with the law's response to female perpetrators prosecuted in international criminal institutions. The chapter interrogates the possibilities and limitations of international criminal law: from local structures that usher the transition to peace after war to alternative modes of listening and developing artefacts for the memories of violence, armed conflict and transition. In this chapter we look to modes of law that work to undo the gendered legacies of the current structures and the gendered legacies of armed conflict while arguing for a mode of gender analysis that incorporates Wright's notion of 'becoming human' as a sentiment for holding difference as a means to frame alternative human futures. ${ }^{154}$ These themes of memory and listening will be drawn on again in Volume Two in our discussion of transitional justice processes and feminist theories of justice.

Throughout this first volume we examine the laws on war and the laws in war while simultaneously identifying and noting the gendered insecurities produced within peacetime states through military thinking and strategies. We note how international criminal law functions as a bridge away from armed conflict, a space of recording and remembering

154. Shelley Wright, 'The Horizon of Becoming: Culture, Gender and History after September 11' (2002) 71 Nordic Journal of International Law 215 
the excesses of violence and a space where the gendering of this violence can be thought through.

By concluding the text with an account of international criminal law, we open the space for Volume Two which further examines the period understood as post-conflict. Volume Two also introduces further spaces of gender analysis, drawing on transnational feminisms, feminist peace activism, anti-militarism and disarmament projects, as well as critical disability studies/crip theory and posthuman feminisms alongside indigenous theories of law and justice. In analysing the role of international law in post-conflict we return to reflecting upon the intertwined reality of war and peace, highlighting the militarism of peacekeeping, the gendered insecurities prevalent in peacebuilding missions and the dominance of military actors in peace agreements. The second volume then concludes with a study of transitional justice processes, beyond international criminal law, and of military technologies to question what constitutes peace and to demonstrate how specific, western, liberal, knowledge structures frame and inform international law. This opens the discussion to a study of the inclusion of a wider understanding of insecurity that addresses environmental, health and gendered insecurities that traverse conflict and peacetime states in a global fashion. Volume Two thus complements this volume, which argues for a gender analysis of the law of war and peace commencing with difference and drawing in the work of multiple feminist perspectives, including intersectional, structural bias, posthuman and queer scholars. This is an approach that interrogates law at a structural level and undoes the dominant legal narratives of gender equating to women, and women as vulnerable, as defined by her sexuality and requiring protection. 